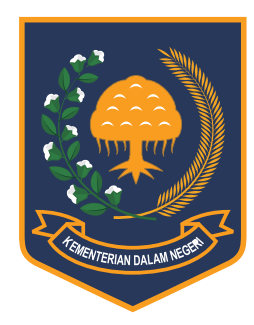

JURNAL BINA PRAJA

e-ISSN: 2503-3360 | p-ISSN: 2085-4323

Accreditation Number

21/E/KPT/2018

http://jurnal.kemendagri.go.id/index.php/jbp/index

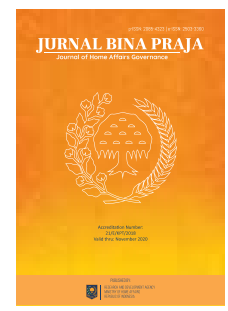

\title{
Regional Autonomy Oversight MOdels \\ IN DENMARK AND ZIMBABWE \\ ANd Alternative Regional Autonomy Oversight Model \\ IN INDONESIA
}

\author{
Hadi Prabowo ${ }^{1, *}$ \\ ${ }^{1}$ Institute of Governance of Home Affairs \\ Jl. Ir. Soekarno KM 20, Jatinangor, Sumedang \\ West Java, Indonesia, 45363
}

Received: 23 April 2020; Accepted: 14 May 2020; Published online: 28 May 2020

DOI: $10.21787 / \mathrm{jbp} .12 .2020 .64-74$

\begin{abstract}
Law No. 12 of 2017 concerning the Guidance and Oversight of the Administration of Regional Governments apparently has not provided sufficient power for the implementation of regional autonomy in Indonesia. In fact, a number of cases that undermine the implementation of regional autonomy still occur frequently. There are many contributing factors, including the current regional autonomy oversight system. The Regional Autonomy Implementation Monitoring Committee (KPPOD), for example, noted implementing regulations related to sanctions for regional governments that commit violations or disobey, such as delays in preparing regional budgets, negligence in national programs, or noticeless overseas travels, were not firm yet. On the other hand, guidance and oversight were still considered weak. Therefore, this study intended to provide an overview of regional autonomy oversight models in Denmark and Zimbabwe while trying to provide a solution for the regional autonomy oversight model in Indonesia. To achieve this goal, this study used a literature study method to gather various relevant information with a qualitative approach. This approach was considered appropriate because regional autonomy oversight was multidimensional. The results showed that such a regional autonomy oversight model as applied in Denmark was needed to control regional governments from implementing policies that could harm public interest. Furthermore, the oversight must be carried out by looking at the problems and the actual conditions in the regions in more detail. This study also offered a regional autonomy oversight model, which has dimensions of human resources, acceptance, development, and innovation.
\end{abstract}

Keywords: Oversight, Regional Autonomy, Regional Governments.

\section{INTRODUCTION}

Regional autonomy is one of the policies adopted by the Indonesian government to reduce centralistic tendencies of the central government as during the New Order era. Through regional autonomy, the orientation of development is more bottom-up than top-down (Sumbu, 2001, p. 53). This means that communities and regions are given development authority in line with their characteristics. The granting of authority is also in line with the decentralization principle, which is the core foundation of regional autonomy in Indonesia.
It provides opportunities for regions to be able to function independently in the political, governmental, economic, social, and cultural aspects within the framework of the Unitary State of the Republic of Indonesia. It is also a form of government obligation to create public welfare. However, in reality, almost all government activities in regions are related to personal interests and the interests of political parties promoting regional heads, which may influence decisions or policies taken by governors, regents, or mayors. There are many unresolved irregularities in the administration of government. This shows that the regional autonomy oversight has not been

\footnotetext{
* Corresponding Author

Phone : +6281331805805

Email : hprabowo0904@gmail.com
} 
carried out optimally (Sanjaya, 2015, p. 37). Not only does optimizing regional autonomy oversight realize the ideals of regional autonomy to improve public welfare but also it prevents irregularities and abuse of authority (Diamantina, 2010, p. 37).

Regional autonomy oversight is mandated by the provisions of Article 378 of Law No. 23 of 2014 concerning Regional Governments. The oversight paradigm has turned from simply irregularity identification to effective achievements of missions and goals of an organization. Indonesia already has a legal basis for regional autonomy oversight and guidance with Government Regulation No. 12 of 2017 concerning the Guidance and Oversight of the Administration of Regional Governments. Regional autonomy guidance was initiated by the central government as an effort to facilitate the process of implementing autonomy. As for oversight, it aimed to maintain the consistency and effectiveness of the implementation of autonomy.

However, in practice, the oversight of the central government over regional governments has not been optimal (Pengawasan Tidak Optimal, n.d.). A research by the 2016 KPPOD, for example, noted implementing regulations related to sanctions for regional governments that commit violations or disobey, such as delays in preparing regional budgets, negligence in national programs, or noticeless overseas travels, were not firm yet. (Pengawasan Tidak Optimal, n.d.). On the other hand, guidance and oversight were still considered weak (Fajri, 2019). In fact, state administrators have an important role in advancing the governments by providing the best services to the people. One of the obstacles of oversight so far is the weak coordination among institutions. For example, government agencies, such as immigration offices and regional governments, are weak in verification, oversight, and data collection, hence many cases of visitor visa misuse by illegal foreign workers (Sinaga, 2016). The condition is compounded by sectoral egos, resulting in regions often having difficulty in obtaining development and oversight programs from several institutions with uncoordinated time. In addition, development and oversight programs are also lacking in innovation. As a result, there has been no positive breakthrough that can provide values added and benefits for the people (Fajri, 2019).

Current oversight is often considered failing to meet expectations. It is due to the lack of commitment of the regional heads and heads of the regional government agencies who were overseen. Almost all government activities and programs that are monitored and evaluated by the oversight agency are closely related to the interests of regional heads, both institutionally and personally. On the other hand, the oversight agency lacks authority to optimize oversight. In addition, the oversight agency still lacks authority to force the supervised agencies to have the results of the inspection followed up on (Siregar, 2018).

The various examples of cases of oversight obstacles above show that the prevailing regional autonomy is problematic not only in the implementation aspect but also in the fundamental aspect. The implementation of regional autonomy and decentralization is still felt only on the surface and has not regarded the fundamental target of regional autonomy, i.e., regional independence. Regional governments were still too dependent on the central government (Apituley, 2013). For example, their dependence on Transfer to Regions and Village Funds (TKDD) was still very high. On the national average, the dependence of regional budgets on TKDD was $80.1 \%$. Meanwhile, the contribution of regionally-generated revenues was only around 12.87\% (Nugraha, 2019).

As a result, since the beginning of the reform period, regional dependence on the central government has not changed despite regional autonomy. Effective implementation of regional autonomy policy has not been able to solve the problems (Witono, 2007, p. 21). The problems of regional autonomy are present not only in the regulatory context, such as division of functions, but also in the context of regional government leadership discretion. This discretion is often not in accordance with existing regulations, especially the Regional Autonomy Law. In fact, (without ignoring the bad behavior of some regional heads involved in corruption), a number of policies directly from regional heads become a tool of abuse of power, especially against regional investments and development, and lead to the arrests by the Corruption Eradication Commission (KPK). It can be seen from the large number of regional heads caught red-handed by the KPK. Based on data from Indonesia Corruption Watch (ICW), there were at least 104 cases of corruption involving regional heads, the highest in 2018, reaching 29 cases (Sasongko, 2018). For this reason, the governments need to improve themselves to maintain the existence of regional autonomy. In the short-term context, the central government has the responsibility for improving patterns of and approaches to regional autonomy. One of the ways is through the implementation of an effective oversight model to maintain and oversee the regional government framework.

Studies that discuss regional autonomy oversight models are still very rare, if not absent, in Indonesia. Some studies only discuss the oversight by the oversight agency. For example, Apituley (2013); Suharti \& Hutahaean (2018); and Kusnadi 
(2017) studied regional financial oversight in the implementation of regional autonomy. They agreed that regional financial oversight was very important because many regions were still dependent on the central government. Besides, planning, oversight, and control were considered to have reasonable impacts on regional budgets. As for the role of oversight agencies, such as regional inspectorates, according to Matei et al. (2017) did not have an optimal function. Matei et al. recommended a number of strategies, for example, additional oversight officers; improvement of the competence of the Government Internal Oversight Apparatus (APIP); an increase in the budget allocation for oversight; additional oversight facilities; APIP's role optimization as a consultant and catalyst; strict sanctions on regional working units (SKPD) that are negligent or less committed to the implementation of oversight; and joint commitment of regional governments to oversight.

Another study regional autonomy oversight has also been conducted by Prabowo (2019). His analysis shows a significant correlation between the implementation of policies and the development and oversight of the effectiveness of regional autonomy. He also concluded the need for a new alternative model of development and oversight policies for the effectiveness of regional autonomy. Some studies also discuss the role of APIP in regions. Among them are that conducted by Maharjono (2018) and Engkus et al. (2019). In general, they concluded the role of oversight agencies was not played optimally. Among the causes were low public service quality because the transfer of authority was often misunderstood or misused. Other factors included resources, regulations, administrative audit practices, internal communications, and lack of understanding.

Speaking of regional autonomy oversight, it is very important to compare several studies related to regional autonomy in various regions. A regional autonomy study in Asia, for example, was conducted by Liu (2018). In his study, Liu concluded that there were many problems in implementing the regional autonomy law in China. Other problems included difficulties in applying the principle provisions on the right to autonomy, lack of oversight mechanisms and legal responsibility, and imperfections of supporting laws. Another study on regional autonomy in China was also carried out by Wei \& De-rui (2016). More like in Indonesia, the financial management of minority autonomous regions in China was under the control of the central government. This situation was not in accordance with the functional orientation of ethnic minority regional autonomy in China and not in line with the global trend of regional financial autonomy. The researchers saw the unrealistic financial autonomy in autonomous regions in China.
Autonomous regions need increased budgets while state revenues were insufficient, resulting in double pressures from the center for autonomous regions.

In contrast to some countries in Asia, the regional autonomy models in Europe, according to Melamed (2019), adopted the three-tier federalism system. The success of regional autonomy is determined by the actions of central governments and not by activities on behalf of regional autonomy within the European Union (EU). The EU does not have control over autonomous regions. As a case in point, the opposition of the Finnish government which demanded full autonomy over Åland and the opposition of the Spanish government against Catalonia always failed. In fact, they continue to lobby the EU for European support for their efforts for national separation. Likewise, support from the British government for greater Scottish autonomy and from the Belgian government for increasing Flemish autonomy have coincided with increased real autonomy for these two regions.

Unlike in Europe, according to a study by González (2016), autonomy in the Caribbean faced huge challenges. The Frente Sandinista de Liberación Nacional (FSLN) continued its vision of national integration for the Caribbean Coast and promoted a political agenda that ultimately aimed to promote autonomy to realize the right to independence, determination of Indigenous Peoples and Afrodescendants.

Considering the results of the above studies, this study seemed to be increasingly important and interesting because there were not many studies specifically on regional autonomy, mainly related to the ideal model of regional autonomy oversight. In addition, as a comparison, the study would also look at the implementation of regional autonomy in Denmark and Zimbabwe, in which the regional autonomy had never been compared with Indonesia. For this reason, this study intended to fill the lacuna. This study raised the issue of current regional autonomy oversight with the elaboration on: (i) the regional autonomy oversight in Denmark and Zimbabwe; and (ii) an ideal regional autonomy oversight model for Indonesia.

\section{MeThOD}

This study focused on regional autonomy in Denmark and Zimbabwe and the ideal model of regional autonomy oversight to apply in Indonesia, using a combination of descriptive method and qualitative approach. Qualitative approach was considered appropriate because the variables of autonomy were considered multidimensional (Alwasilah, 2003). In addition, this study is also literature study, which uses books and other literature 
as the main objects (Hadi, 2000). To describe the studied phenomena, various perceptions and supporting documents related to regional autonomy were explored. Data were collected in the form of electronic and physical documents and reports in mainstream mass media to enrich the analysis. In addition, the study compared regional autonomy practices in Denmark and Zimbabwe. Denmark was chosen because it was considered to be a country with effective implementation of regional autonomy While Zimbabwe was chosen for the ineffective implementation of its regional autonomy. The two countries were chosen because they represented countries in respectively Europe and Africa with similar regional autonomy practices to that in Indonesia. For example, their laws provided flexibility to autonomous regions, like Indonesian laws did.

\section{ReSULTS AND DiscuSSION}

This section will discuss regional autonomy oversight in Denmark and Zimbabwe and an alternative regional autonomy oversight model for Indonesia.

\section{A. Regional Autonomy Oversight in Denmark}

In general, the principles and ideals of regional autonomy in the world are to give authority to regions to take care of and regulate their governmental affairs. Autonomous regions have the authority to make policies to provide services, increase participation and initiatives, and empower people for public welfare (Rosalina, 2017a).

The same goes with oversight. Since regional autonomy was introduced by Law No. 5 of 1974 concerning Fundamentals of Administration in Regions, regional government oversight has served as the manifestation of responsibilities of the central government for the maintenance of national unity and territorial integrity of the Republic of Indonesia. According to the law, there are three types of oversight, i.e., preventive oversight, repressive oversight, and general supervision (Rosalina, 2017b). Not much different from Indonesia, regional autonomy oversight in the EU is also a solution to the various challenges of decentralization, not least in Denmark (Froy et al., 2011).

Froy et al., (2011) in the working papers released by the Organization for Economic Cooperation and Development (OECD) said there were at least 5 dimensions of the success of regional autonomy in Denmark and other European countries. First, the dimension of information. The guidance by the central government had an important role in creating superior human resources, especially in building the capacity and capability of regional apparatus. It was also important to give awards to the regions with the best human resource development achievements to trigger other regions to achieve the same human resource development. These conditions were expected to create a cycle of human resource development as a strong foundation for strong organizational cultures.

In Indonesia, there has been no award specifically given to individuals, such as oversight officers, in regions. In fact, rewards, incentives, and salaries have an obvious relationship with knowledge, skills, and individual contributions to organizational performance (Saputra, 2014). On the other hand, oversight awards have only been given to autonomous regions represented by the regional heads. In fact, APIP has an important role in preventing corruption (Isnanto, 2019).

In terms of autonomy, the central government has given many awards in various categories, for example, the award for innovative regional heads, the award for best financial management, and so on. The former is a form of appreciation to regional heads for their innovative efforts in developing regions. Regional innovations are expected to really have an impact on public welfare. The financial management award also serves as a motivation to realize good budget management to support regional development programs.

The central government also gives rewards to regions in the form of special incentives grants (Dana InsentifDaerah/DID) through the Ministry of Finance. According to the ministry, the budget allocation for DID continues to increase. In 2020, the government budgeted Rp15 trillion, up 50 percent from last year, which was Rp10 trillion (Mahardhika, 2019). However, in practice, the disbursement of DID is still experiencing problems. Some regions complained too many required criteria made it difficult for even many potential regions to get DID (Pryanka, 2020).

Second, the dimension of tailor-made policies. Tailor-made policies are policies designed to provide convenience for both parties (in this case, the government and the people) with easy and efficient process and transparency as the main basis (Head, 2013). The central government serves as a glue for regional interests. One of the risks of regional autonomy is strong regional sentiment, which may trigger regional fragmentation. The oversight function is one of the government's preventive measures to minimize the fragmentation. The government continues to encourage the creation of a nationalist decentralization (Erviantono, 2010). This means that national values are fused with strong local values. It can create an area with strong local values and an identity as part of the state at once. 
Regional autonomy in Indonesia is also expected to promote tailor-made policies, in the sense of a more participatory, transparent, and accountable public policy-making process, and more responsive regional governments to local needs and dynamics. Local wisdoms can be the basis for regional governments to understand the dynamics of regional administration to increase regional public participation. This is because in general local communities still uphold local customs and cultures (Risal, 2016).

However, tailor-made policies have not been adopted optimally. Not many regional governments understand the local wisdoms in their regions, so that public participation does not increase. In fact, the spirit of regional autonomy plays a role when local people really participate in making public policies in their regions (Risal, 2016). As a result, regional autonomy has actually posed a strong threat of disintegration, along with the weakening of the central government's ability to exercise power effectively over regions. For this reason, the role of regional governments is important because they are the front-line guards of the national unity. They must be able to reduce regional conflicts. It may be possible by understanding the people. The entrance is culture, a part of which is local wisdom. Strong local wisdoms and support from the governments amid modernity will be able to strengthen the sense of national unity and love of local people for the existence of Indonesia (Kristiyanto, 2017, p. 172).

Third, the dimension of innovation. In line with the dimension of information with the development of superior human resources, the central government's oversight in Indonesia also encourages horizontal relations among regions, especially in the exchange of information. Inter-regional collaboration can be created by mutually exchanging experiences and good practices to create superior human resources. The exchange of information can be done in various ways, such as through seminars, training and development, and workshops.

Countries such as Denmark, Belgium, Canada, and the Netherlands, collaborate to build the legitimacy of regional policy objectives. This has a maximum impact on the implementation of policies in regions. Regional stakeholders, such as employers, workers' organizations, and regional governments share common goals related to regional work plans and support the implementation of policies, thereby increasing positive impacts. Collaboration and partnerships contribute to making political and administrative management accountable for achieving good results (Froy et al., 2011).

When oversight spurs collaborative governance (by public and private sectors in managing and planning a country, regions, and cities), regional autonomy is far more effective. Collaborative governance will have an impact on regions in several cases, such as; a) freedom of determination and autonomy, with which there will be collaboration among initially individual actors, b) autonomous units, which seek to work together optimally to achieve mutual goals despite the merge, c) interdependent relationships to facilitate the fulfillment of resources and the achievement of shared goals, and; d) the combination of the strengths of the actors involved to strengthen performance (Eprilianto et al., 2019).

Fourth, the dimension of overcoming the silo effect. Guidance and oversight of regional governments show the presence of the central government in the implementation of regional autonomy. The silo effect often occurs when regions are reluctant to share information, goals, and methods in administering their governments. It results in deteriorating intergovernmental coordination and transparency, which leads to a deterioration in the organizational cultures and distrust of the governments. The presence of the central government ensures that the silo effect will not occur in the implementation of regional autonomy.

Denmark is a country that is prepared to anticipate the silo effect, for example in ensuring the management of labor policies set by the regions. In recent years, Denmark has made an important transition by giving full responsibility to Danish cities, while maintaining a strong system of control from national manpower authorities. Every city in Denmark plays an important role in combining approaches that meet individual and public needs. They take into account the problems of the wider community when planning manpower policies and programs. The regional manpower councils also ensure that the system includes horizontal accountability at the regional level through the involvement of regional social partners. At the same time, the national and regional manpower agencies set targets and ensures minimum standards are met. The Danish manpower system achieves a balance between accountability and flexibility. Local actors and stakeholders work together in targeting manpower measures in accordance with local challenges and needs.

Fifth, the dimension of accountability. Guidance and oversight by the central government are expected to create accountable regional autonomy. In the implementation of decentralization, the Danish Ministry of Manpower implement two ways of exercising power over Koege and other Danish cities. One is through substantive policy objectives and performance measures that essentially provide relative capabilities for each and every city to implement national strategies. The other way by urging Koege and other Danish cities to formulate 
local goals to deal with unemployment. The ministry carries out important procedural actions of power; otherwise, the cities run autonomously (Triantafillou, 2012).

In Indonesia, the central government does not yet have measurable success indicators along with a systematic evaluation stage, so that regional governments do not have a clear role and function in achieving the expected performance. With measurable success indicators and evaluation, a modern performance management system will be created, which serves as a liaison between the central government and regional governments in the implementation of regional autonomy.

It shows that guidance and oversight can be categorized as an exercise of power carried out by the central government over regional governments. In line with the concept of decentralization, which is the granting or transfer of power from the center to regions, the values and contributions of the Central Government to regional governments are not completely lost. The guidance and oversight by the central government aim to ensure that the process of delegation of power runs as it should and that the delegated power is exercised optimally. The central government has a set of performance indicators to measure the level of effectiveness and efficiency in the implementation of regional autonomy. Oversight by the central government ensures that the performance of regional governments is appropriate and in line with the performance indicators. As for guidance, it functions when a regional government fails to achieve the performance indicators (Azma, 2017).

\section{B. Regional Autonomy Oversight in Zimbabwe}

In contrast to Denmark, Zimbabwe applies central government oversight over regional governments through four main dimensions. First is the establishment of regional government institutions and the enactment of relevant regulations. Second, the role and function of the central government's regulations in aligning the function of regional governments through policies related to regional governments. Third, oversight is ongoing in the function of regional governments through requests for information and access to records, including investigations of allegations of corruption and other deviant behaviors. In this context, oversight may be involved in the suspension or dismissal of board members due to deviant behaviors or poor performance. Fourth, the intervention of the central government in appointing administrators, commissioners, or aldermen to replace the suspended investigation board members (Urban Councils Act, 2015 [Chapter 29:15], 2001).
The dimensions of oversight in Zimbabwe show that the structure and practice of regional autonomy oversight in Zimbabwe are a legal function, where regional governments are only an embodiment of the policies and implementation of the delegation of authority. However, it is a question whether strong restrictions on the function of authority of regional governments can optimize the potentials in facilitating development and sustaining democracy. The conditions make innovations and responsibilities for regional needs can only directly be measured in discretion given under the legal framework (Vincent S, 2015).

It shows that oversight is a legal action taken by the central government over regional governments in the implementation of decentralization. Zimbabwe emphasizes the formal legal dimensions of the central government in carrying out various interventions in regional governments' affairs, where the central government still has a strong and binding role and function in the implementation of decentralization. On the other hand, this has directly reduced the ability of regions to administer their own regions. The decentralization is purely the delegation of authority which in its implementation is still regulated and intervened by the central government.

In contrast to Indonesia, where the central government gives freedom to regions in regional fiscal management, the central government of Zimbabwe does not give fiscal autonomy to municipal governments. Zimbabwe's 1966 Autonomy Law does not guarantee financial autonomy of municipal councils. In the absence of a source of income, municipal governments only focus on services. In addition, municipal government revenues for alternative financing options are also limited. Although regional governments have a strong legal basis, the regulation of the Minister of Home Affairs of Zimbabwe is a barrier Regional government are not given broad authority regarding regional revenues. This leads to a wide gap between revenue and production figures. The absence of rules on allocation funds for regions is another proof of the lack of regional financial autonomy (Marumahoko \& Fessha, 2011).

Regional autonomy in Zimbabwe actually began after independence in 1980 and has changed several times, like in Indonesia. The changes aimed to improve the efficiency and effectiveness of regional governments. The focus of the changes included the elimination of racial discrimination, the elimination of two development systems that emphasize white and black areas, democracy development, good administration, decentralization, and the alignment of politics and policies of regional government institutions with national strategies and vision 
for development. But the system has deteriorated significantly due to over-intervention by the central government in regional problems (Marumahoko \& Fessha, 2011).

Political conflicts also affect the autonomy system in Zimbabwe. They include conflicts in regional head elections and disputes between the Minister of Home Affairs and regional governments and regional people's representative councils. The autonomy system that was appreciated by many during the 1980s and 1990s showed the slow process of political, administrative, and democratic development in Zimbabwe (Jonga, 2014).

\section{The Ideal Regional Autonomy \\ Oversight Model for Indonesia}

The central government has a role and function as a guardian and builder of national values, so that regional governments have clear boundaries and corridors regarding the national foundation. This means that national values need to be built along with local wisdoms in regional autonomy. The role and function of the central government in regional autonomy is not only as an overseer but also as a collaborator in the development and activities of regional governments. However, excessive regional autonomy often results in fragmentation and dominant local values over national values.

In its implementation, current regional autonomy oversight is considered not effective yet, especially in terms of poor coordination among components and poor program planning with sectoral ego. It means that regions with sectoral ego are still dominant in the administration of government. It often creates local strongmen or little kings in regions with strong local traditions. As a result, regional relationships are often impeded vertically, horizontally, and diagonally, leading to ineffective regional performance (Prasetia, 2018). The situation may directly cause the silo effect and regional fragmentation.

Non-compliance of some regions with Minister of Finance Regulation No. 35 of 2020 was an example of the weakness of regional autonomy oversight. Under the regulation, the rationalization of spending on goods and services is at least 50\%. The same holds true for the rationalization of capital expenditure. However, some regions did not comply with the mandatory thresholds. As a result, the central government decided to transfer only $65 \%$ of general purpose grants (Dana Alokasi Umum/DAU) to 380 regions because they had not implemented the mandate of cutting regional spending as an effort to accelerate the handling of COVID-19. Furthermore, the postponed transfer of the remaining 35\% may allow the regional governments to cut spending related to public services, which ultimately harms public interest. The postponed transfer will greatly affect the regions because, in most regency governments, the DAU are greater than the regionally generated revenues. If the transfer of the remaining $35 \%$ of DAU is delayed, there is potential for public spending to be cut. It depends on the fiscal space in the regional budgets of each region. Because, if the DAU transfer is postponed, spending related to public services will most likely be adjusted (Purnamasari, 2020).

Based on this phenomenon, a new model that is able to optimize the role and function of oversight in the implementation of regional autonomy is needed. Among potential models are those focusing on human resources, acceptance, development, and innovation (Prabowo, 2019). There are currently two oversight regional autonomy models, i.e., preventive oversight model and repressive oversight model. Both models are aimed at regional legal products and certain actions of regional governments carried out through the authority of ratification (goedkeuring) in the preventive oversight and the authority of cancellation (vernieging) or suspension (schorsing) in the repressive oversight. The preventive oversight model is implemented by ratifying or refusing to ratify regional regulations prepared by regional governments. The problem is that this model is not significant for the effectiveness of budget control (Peuranda et al., 2014, p. 16).

With regard to human resources, human resources need to have competence, ability, endurance, visionary, wisdom, and be able to create a conducive organizational culture. Human resources are inseparable from the successful implementation of regional autonomy oversight policies. Both quantitative and qualitative researchers have found that there is a very strong and dominant element influencing the successful implementation of regional autonomy guidance and oversight policies.

In Indonesia, the Finance and Development Supervisory Agency (BPKP) is one of the institutions tasked with conducting internal oversight of the running of the state under Presidential Regulation No. 192 of 2014 concerning the Finance and Development Supervisory Agency. BPKP has the task of overseeing state and regional finance and development. In performing its tasks and functions, the agency has supervisory human resources called APIP. The function of APIP is currently weak (Mulyatini, 2018). The reason is that regional APIP are appointed and responsible to regional heads, as APIP in ministries or institutions are appointed and responsible to the leaders of their respective ministries or institutions (Widiyanto, 2017). 
In addition, based on the results of the capability assessment of APIP (2010-2015) by BPKP, 404 or 85.23\% of APIP were still at level 1 (initial), 69 or $14.56 \%$ were at level 2 (infrastructure), and only one or $0.21 \%$ was at level 3 (integrated), indicating that APIP had not been able to guarantee the administration process in compliance with regulations and prevent violations (Mulyatini, 2018).

Therefore, human resources with the ability to achieve high performance and produce outputs and outcomes are very important. The performance and quality of human resources can be assessed from their level of responsibility and competence. Similarly, the responsibility of human resources can also be seen in the clear division of basic tasks and functions (Midesia, 2015, p. 80).

As for the acceptance dimension, good acceptance between the overseeing party (central government) and the overseen party (regional governments) is needed. Both parties need to have good social intelligence to accept each other's policies. Since they interact with each other to agree on certain substances, there must be mutual acceptance of the substances. Acceptance becomes a very strong and dominant factor in the successful implementation of regional autonomy guidance and oversight policies (Prabowo, 2019).

The DAU transfer postponement shows that there is no acceptance dimension in the current regional autonomy system. The sanction resulted from the regions' non-compliance, implying their disagreement on the central government's policy. Such sanction is indeed good to shock the noncompliant regional governments and is in accordance with Article 36 of Law No. 12 of 2017 concerning the Guidance and Oversight of the Administration of Regional Governments. However, it is also considered not reasonable to be applied equally.

For example, the administrative sanction as referred to in Article 36 seems to ignore the actual problems in some regions, especially when applied in eastern regions. It fails to see in detail the real conditions faced by regional governments, especially when they are required to rationalize their regional budgets despite limited fiscal space. When most regional governments are still very dependent on the funds from the central government, Potential regionally generated revenues will also be affected by the economic slowdown due to the pandemic. For example, technical problems, such as networks and internet connections, also become obstacles in eastern Indonesia. When a pandemic is followed by a working-from-home policy, the performance of the regional governments will slow down. Communication and coordination are carried out online. That is why most of the provinces, regencies, and cities that were sanctioned are from eastern Indonesia.

As for the development dimension, it is carried out in every implementation of development-oriented guidance and oversight of regional autonomy. The implementation of oversight policies really requires a development step. Factual conditions in the implementation of regional autonomy continue to change along with increasingly complex problems. Therefore, the implementation of oversight policy must also continue to develop. Lastly, the innovation dimension is a breakthrough and acceleration step towards the implementation and substance of oversight policies. Development and innovation always go hand in hand. Regional autonomy requires updates and added values in the oversight. Regional autonomy guidance and oversight requires updates and added values to be effective, not only routines without knowing the factual conditions of the autonomous regions.

\section{ConClusion}

Regional empowerment and autonomy cannot be separated from the granting of authority to regions to regulate their affairs within the limits given by legislation. However, oversight mechanisms are still needed so that regional policies encourage regional empowerment and comply with national policies. Law No. 12 of 2017 concerning the Guidance and Oversight of the Administration of Regional Governments apparently has not provided sufficient power for the implementation of regional autonomy in Indonesia. In fact, a number of cases that undermine the implementation of regional autonomy still occur frequently. The main problem is the current oversight system.

Therefore, a strong oversight model is needed to prevent regional governments from implementing policies that could harm public interest. Furthermore, the oversight must be carried out appropriately by looking into more detail the problems and real conditions in regions. In this way, it will be easier for the central government to determine interventions for regions, just like Denmark, which is better prepared to anticipate regional distrust of the central government.

To that end, the oversight model recommended by this study is that which has dimensions of human resources, acceptance, development, and innovation. The model is not expected to solve various problems but to find solutions that are deemed appropriate in the context of regional autonomy in Indonesia. It also assumes that poor implementation of regional autonomy oversight can be minimized. 


\section{ACKNOWLEDGMENT}

The authors would like to thank the Secretariat General of the Ministry of Home Affairs and the Institute of Public Administration (IPDN) for any moral and material support for completing this article. We would also like to appreciate everyone who helped and assisted us during the research.

\section{REFERENCES}

Alwasilah, A. C. (2003). Pokoknya Kualitatif: DasarDasar Merancang dan Melakukan Penelitian Kualitatif. Pustaka Jaya.

Apituley, L. G. F. (2013). Pengawasan Penggunaan Keuangan Daerah dalam Pelaksanaan Otonomi Daerah. Journal Uniera, 2(1). https:// journal.uniera.ac.id/abst/37/pengawasanpenggunaan-keuangan-daerah-dalampelaksanaan-otonomi-daerah

Azma, M. A. (2017). Pengaruh Motivasi, Pengetahuan tentang Pengelolaan Keuangan Daerah dan Intensitas Pembinaan Aparat Inspektorat terhadap Kualitas Hasil Audit Inspektorat (Studi Empiris pada Inspektorat Kota Pariaman dan Kabupaten Padang Pariaman). JOM Fekon, 4(1), 309-322. https://jom.unri.ac.id/index.php/ JOMFEKON/article/view/12345

Diamantina, A. (2010). Pengawasan Atas Penyelenggaraan Pemerintahan Daerah untuk Mewujudkan Pemerintahan Daerah yang Efektif dan Efisien. Masalah-Masalah Hukum, 39(1), 36-43. https://doi.org/10.14710/ mmh.39.1.2010.36-43

Engkus, Hoerudin, C. W., \& Maolani, D. Y. (2019). Supervision and Control of The Government Internal Supervisory Apparatus in The Implementation of Regional Autonomy. International Journal of Science and Society, 1(1), 56-69. https://doi.org/10.200609/ijsoc. v1i1.16

Eprilianto, D. F., Pradana, G. W., \& Sari, Y. E. K. (2019). Digital Inovasi Sektor Publik: Efektivitas Kolaborasi dalam Implementasi Inovasi Desa Digital. Jurnal El-Riyasah, 10(2), 127-145. https://doi.org/10.24014/jel.v10i2.8909

Erviantono, T. (2010). Desentralisasi dan Kemandirian Kelembagaan Lokal. Interaktif: Jurnal IImu-IImu Sosial. http://interaktif.ub.ac.id/index.php/ interaktif/article/view/102

Fajri, R. (2019, April 30). Pentingnya Pengawasan dan Pembinaan di Era Otonomi Daerah. Mediaindonesia.Com. https://mediaindonesia. com/read/detail / 232753 - pentingnyapengawasan-dan-pembinaan-di-era-otonomidaerah
Froy, F., Giguère, S., Pyne, L., \& Wood, D. E. (2011). Building Flexibility and Accountability Into Local Employment Services: Synthesis of OECD Studies in Belgium, Canada, Denmark and the Netherlands (2011/10). 1-96. https://doi. org/10.1787/5kg3mkv3tr21-en

González, M. (2016). The Unmaking of SelfDetermination: Twenty-Five Years of Regional Autonomy in Nicaragua. Bulletin of Latin American Research, 35(3), 306-321. https:// doi.org/10.1111/blar.12487

Hadi, S. (2000). Metodologi Research. Andi Offset.

Head, G. (2013, April 8). Tailor-Made Policies Provide Good Options for Medical and Professional Liability Market. Insurance Journal. https:// www.insurancejournal.com/magazines/magfeatures/2013/04/08/286906.htm

Isnanto, B. A. (2019, September 25). Kemendagri Beri Penghargaan Pengawasan Terbaik untuk 5 Pemprov. DetikNews. https://news.detik.com/ berita-jawa-tengah/d-4721223/kemendagriberi-penghargaan-pengawasan-terbaik-untuk5-pemprov

Jonga, W. (2014). Local Government System in Zimbabwe and Associated Challenges: Synthesis and Antithesis. Archives of Business Research, 2(1), 75-98. https://doi.org/10.14738/ abr.21.89

Kristiyanto, E. N. (2017). Kedudukan Kearifan Lokal dan Peranan Masyarakat dalam Penataan Ruang di Daerah. Jurnal Rechtsvinding, 6(2), 159-177. https://rechtsvinding.bphn.go.id/artikel/ artikel eko.pdf

Kusnadi, A. (2017). Re-Evaluasi Hubungan Pengawasan Pusat dan Daerah Setelah Berlakunya UU No. 23 Tahun 2014 tentang Pemerintahan Daerah. Arena Hukum, 10(1), 61-77. https://doi.org/10.21776/ ub.arenahukum.2017.01001.4

Liu, L. (2018). Problems and Countermeasures in the Implementation of the Law of the People's Republic of China on Regional Ethnic Autonomy. Proceedings of the International Conference on Contemporary Education, Social Sciences and Ecological Studies (CESSES 2018), 342-346. https://doi.org/10.2991/cesses-18.2018.77

Mahardhika, L. A. (2019, September 11). Dorong Investasi Daerah, Pemerintah Anggarkan DID Rp15 Triliun (A. Aris (Ed.)). Bisnis. Com. https://ekonomi.bisnis.com / $\mathrm{read} / 20190911 / 9 / 1147205 /$ dorong-investasidaerah-pemerintah-anggarkan-did-rp15-triliun

Maharjono, I. A. W. (2018). Strategi Peningkatan Kapabilitas Aparat Pengawas Intern Pemerintah (APIP) dengan Internal Audit Capability Model 
(IA-CM) (Studi pada Inspektorat DIY) [Universitas Gadjah Mada].http://etd.repository.ugm.ac.id/ home/detail_pencarian/157411

Marumahoko, S., \& Fessha, Y. (2011). Fiscal autonomy of urban councils in Zimbabwe: A critical analysis. Law, Democracy \& Development, 15(1), 1-22. https://doi.org/10.4314/ldd.v15i1.9

Matei, A. M., Karamoy, H., \& Lambey, L. (2017). Optimalisasi Fungsi Inspektorat dalam Pengawasan Keuangan Daerah di Kabupaten Kepulauan Talaud. Jurnal Riset Akuntansi Dan Auditing “Goodwill," 8(1), 86-96. https://doi. org/10.35800/jjs.v8i1.15328

Melamed, E. V. (2019). Regional autonomy movements in Europe: National governments and the EU [University of Illinois]. http://hdl.handle. net/2142/104945

Midesia, S. (2015). Pengaruh Rasio Aktivitas, Profitabilitas, dan Pasar Terhadap Return Saham: Studi Perbandingan Antara Saham Konvensional dan Syariah di Indonesia [Universitas Syiah Kuala]. https://etd.unsyiah.ac.id/index. php? $\mathrm{p}=$ show_detail\&id $=20738$

Mulyatini, N. (2018). Model Peningkatan Kapabilitas Sumber Daya Aparat Pengawasan Internal Pemerintah di Jawa Barat. Ekonologi, 5(1), 283286. https://doi.org/10.2827/jeim.v5i1.1358

Nugraha, Y. N. (2019, January 20). Ketergantungan Fiskal Daerah Dalam Pelaksanaan Desentralisasi Fiskal di Indonesia. Kemenkeu.Go.Id. https:// www.kemenkeu.go.id/publikasi/artikel-danopini/ketergantungan-fiskal-daerah-dalampelaksanaan-desentralisasi-fiskal-di-indonesia/

Pengawasan Tidak Optimal. (n.d.). Kppod.Org. https://www.kppod.org/berita/view?id=547

Peuranda, J. H., Satriawan, R. A., \& Azlina, N. (2014). Pengaruh Pengawasan Preventif dan Pengawasan Detektif terhadap Efektifitas Pengendalian Anggaran (Studi Empiris pada Satuan Kerja Perangkat Daerah di Kabupaten Kampar). JOM Fekon, 1(2), 1-22. https://jom. unri.ac.id/index.php/JOMFEKON/article/ view/3986

Prabowo, H. (2019). Influence of Implementation of Development and Supervision Policy to the Effectiveness of Regional Autonomy in Indonesia. Jurnal Bina Praja, 11(1), 63-73. https://doi.org/10.21787/jbp.11.2019.63-73

Prasetia, A. (2018, April 9). Jokowi: Hilangkan Ego Sektoral Antar-Kementerian/Lembaga. DetikNews. https://news.detik.com/ berita/d-3961835/jokowi-hilangkan-egosektoral-antar-kementerianlembaga

Pryanka, A. (2020, January 15). DPD: Persyaratan Dana Insentif Daerah Terlalu Rumit (G. Amanda (Ed.)). Republika.Co.Id. https://republika.co.id/ berita/q44ost423/dpd-persyaratan-danainsentif-daerah-terlalu-rumit

Purnamasari, D. D. (2020, May 3). Penundaan Transfer DAU Harus Diikuti Pengawasan agar Tak Rugikan Publik. Kompas. https://kompas. id/baca/polhuk/2020/05/03/penundaantransfer-dau-jangan-sampai-korbankan-publik/

Risal, M. (2016). Kearifan Lokal dalam Pembentukan Daerah Otonomi Baru di Era Otonomi Daerah (Studi Kasus: Kearifan Lokal di Daerah Apau Kayan Kabupaten Malinau). Jurnal Administrative Reform (JAR), 4(2), 106-126. https://doi.org/10.30872/jar.v4i2.597

Rosalina, I. F. (2017a, June). Jatuh Bangun Otonomi Pasca-Reformasi. Media BPP, 2(3), 26-29.

Rosalina, I. F. (2017b, June). Otonomi Daerah di Era Dua Orde Besar. Media BPP, 2(3), 22-23.

Sanjaya, L. (2015). Optimalisasi Pengawasan Pengelolaan Keuangan Daerah di Kabupaten Sidoarjo.JKMP (Jurnal Kebijakan Dan Manajemen Publik), 3(1), 35-48. https://doi.org/10.21070/ jkmp.v3i1.179

Saputra, D. (2014). Analisis Kemandirian dan Efektivitas Keuangan Daerah pada Kabupaten dan Kota di Propinsi Sumatera Barat. Jurnal Akuntansi, 2(1), 1-26. http://ejournal.unp.ac.id/ students/index.php/akt/article/view/871

Sasongko, A. (2018, April 26). 104 Kasus Korupsi Kepala Daerah Sudah Diproses KPK. Republika. Co.Id. https://www.republika.co.id/berita/ nasional/hukum/18/04/26/p7ra1e313-104kasus-korupsi-kepala-daerah-sudah-diproses$\mathrm{kpk}$

Sinaga, A. W. (2016, August 3). Koordinasi Antar Lembaga Lemah TKA Ilegal Membanjiri Indonesia. Tribunnews.Com. https://www. tribunnews.com/tribunners/2016/08/03/ koordinasi-antar-lembaga-lemah-tka-ilegalmembanjiri-indonesia

Siregar, M. (2018, June 26). Kendala Dalam Pelaksanaan Pengawasan Terhadap Penyelenggaraan Pemerintahan Daerah. Hariansib.Com. https://hariansib.com/Opini/ Kendala-Dalam-Pelaksanaan-PengawasanTerhadap-Penyelenggaraan-PemerintahanDaerah

Suharti, \& Hutahaean, R. T. (2018). Analisis Perencanaan, Pengawasan dan Pengendalian terhadap Anggaran Pendapatan dan Belanja Daerah Dinas Kelautan dan Perikanan Provinsi Riau. Journal of Economic, Bussines and Accounting (COSTING), 1(2), 167-179. https:// doi.org/10.31539/costing.v1i2.203

Sumbu, H. (2001). Implementasi Kebijakan Otonomi Daerah dalam Konteks Formulasi Kebijakan Otonomi Desa. In Y. T. Winarto \& S. A. Purwanto 
(Eds.), The 1st International Symposium of Journal Antropologi Indonesia (ISJAI) 2000 Proceedings (pp. 51-55). Departemen Antropologi Universitas Indonesia. https://simposiumjai. ui.ac.id/wp-content/uploads/20/2020/03/ Pleno6-Herman-Sumbu.pdf

Triantafillou, P. (2012). Decentralization as the exercise of power and autonomy: the case of Danish employment policy. Journal of Political Power, 5(1), 55-71. https://doi.org/10.1080/2 158379X.2012.660322

Vincent S, C. (2015). Central-local Government Relations: Implications on the Autonomy and Discretion of Zimbabwe's Local Government. Journal of Political Sciences \& Public Affairs, 3(1). https://doi.org/10.4172/2332-0761.1000143
Wei, X., \& De-rui, G. (2016). Financial Governance of Minority Autonomous Regions: from Central Control to Regional Autonomy. Journal of Minzu University of China, 1. http://en.cnki.com.cn/ Article_en/CJFDTotal-ZYMD201601014.htm

Widiyanto, D. (2017, September 19). Pengawasan APIP Masih Lemah. Krjogja.Com. https://www. krjogja.com/peristiwa/nasional/pengawasanapip-masih-lemah/

Witono, T. (2007). Kemiskinan dan Lingkungan dalam Kerangka Otonomi Daerah (Studi Kasus di Lereng Gunung Merapi, Magelang, Jawa Tengah). Sosio Konsepsia, 12(2), 21-32. https:// doi.org/10.33007/ska.v12i2.627

Urban Councils Act, 2015 [Chapter 29:15], 1 (2001). https://zimlii.org/zw/legislation/ act/2001/222001 